\title{
Board Diversity, Company's Financial Performance and Corporate Social Responsibility Information Disclosure in Malaysia
}

\author{
Lily Suriana Hassan ${ }^{\mathrm{a}}$, Norman Mohd Saleh ${ }^{\mathrm{b}}$, Izani Ibrahim ${ }^{\mathrm{c}}$ \\ ${ }^{a}$ Kolej Universiti Polytech MARA, Kuala Lumpur, Malaysia \\ ${ }^{b}$ Centre of Governance Resilence and Accountability, Faculty of Economics \& Management, \\ Universiti Kebangsaan Malaysia, Bangi, Malaysia \\ ${ }^{c}$ Department of Finance, Prince Sultan University, Riyadh, Saudi Arabia \\ Corresponding Author: lily@gapps.kptm.edu.my
}

To cite this article (APA): Hassan, L. S., Mohd Saleh, N., \& Ibrahim, I. (2020). Board diversity, company's financial performance and corporate social responsibility information disclosure in Malaysia. International Business Education Journal, 13(1), 23-49. https://doi.org/10.37134/ibej.vol13.1.3.2020

To link to this article: https://doi.org/10.37134/ibej.vol13.1.3.2020

\begin{abstract}
The aim of this study is to investigate the relationship between board diversity, financial performance and disclosure of corporate social responsibility (CSR) information of the Malaysian listed companies. Different from prior literature, board diversity is viewed from the perspective of gender, age, tenure, educational level, professional membership and functional background. We used one explanation i.e. diversity as variety, out of three explanations from a typology in social psychological and organizational management fields. The sample consists of 205 companies listed on Bursa Malaysia. Using regression analysis, a significant positive relationship was noted between the functional backgrounds of directors and the companies' financial performance. The result shows that boards should have diversity in their functional background. The other forms of board diversity such as gender, age, tenure, educational level and professional membership have been found not to influence companies' financial performance. Board professional membership diversity was found to significantly increase the CSR information disclosure. However, other forms of board diversity were found not to influence the CSR information disclosure. These findings may suggest that corporate boards should have diversity in their functional background and professional membership in order to enhance companies' financial performance and CSR information disclosure.
\end{abstract}

\section{Keywords:}

Board diversity, company's financial performance, corporate social responsibility, information disclosure

\section{INTRODUCTION}

Corporate social responsibility (CSR) information disclosure attracts an ethical investment funds (Adams, 2002) and institutional investors (Saleh et al., 2010). Despite the importance of CSR (Adams and Zutshi, 2004; Galbreath, 2009; Ting et al., 2010), the disclosure level was low in early millennium especially in the developing countries (Abdul Rashid and Ibrahim, 2002; Muhammad Jamil et al., 2002; Nik Ahmad and Sulaiman, 2004; Ramasamy and Ting, 2004; Mohamed Zain and Janggu, 2006; Tee et al., 2007; Bursa Malaysia CSR 2007 Status Report). However, based on a survey in 2017, about 97 percent of the top onehundred companies in Malaysia reported sustainability performance that includes CSR activities, which is higher than the global standard (72 percent). This high level of disclosure of CSR activities was recorded after the disclosure was made mandatory by Bursa Malaysia in 2015 (Lo, 2018). To make sure that the provision of information is sustainable in the future, it is still important to understand the reasons why companies provide voluntary 
disclosure on CSR activities. Prior literature suggests that the provision of CSR information is driven significantly by gender diversity on board. This is following the variety of views within a gender diverse board. It is also understood from the literature that diversity aspects of a board lead to superior economic, environmental and social performance (Harjoto \& Rossi, 2019). Nevertheless, not much is understood on a variety perspectives brought in by diversity in board characteristics such as age, tenure, educational level, professional membership and functional background on CSR disclosure. Thus, the aim of this paper is to investigate the role of board diversity on (CSR) disclosure.

It is acknowledged that the board of directors (BOD) becomes the monitoring mechanism for reviewing corporate policy, and approving strategic plans (Chobpichien et al., 2008) to achieve financial and social performance. Thus, it is wise to study board demography factors that might contribute to such decisions. The majority of prior literature that analyse BOD role on corporate disclosure focus on agency perspective of BOD i.e. BOD and its committee's independence or resource dependence perspective i.e. structure, competencies and experience (Chobpichien et al., 2008; Gul and Leung, 2004; Kaymak and Bektas, 2017). Different than others, Huse et al. (2009) have argued that the quality of a board's decision will be higher if the members have diversity in terms of knowledge and expertise compared to decisions made by people with homogeneous backgrounds. It is expected that members of a board of directors will share their diverse knowledge through board discussion (Huse et al., 2009) and this knowledge can be converted into new products, processes and services, which will enhance the company's financial performance (Jiang and $\mathrm{Li}, 2008)$. This diversity factor is of particular importance especially in CSR disclosure since a broad understanding of the market demand from different perspectives is apparent. It can also be expected that the diverse backgrounds of the BOD such as gender, age, tenure, educational level, professional membership and functional background may bring in different perceptions towards CSR in BOD discussions and might influence the board to disclose more CSR information. A number of prior studies associate gender diversity to CSR information disclosure (Barako and Brown, 2008; Mun and Jung, 2018; Post et al., 2011). However, not much coverage on a relatively broader board diversity perspective on CSR information disclosure provided by prior literature. Therefore, different than the majority of prior literature, we question whether BOD diversity affects CSR information disclosure positively? This study is also interested in analysing the effect of board diversity on companies'financial performance, because diversity in knowledge should lead to better decisions and strategies and how company performance could drive CSR disclosure. To this end, we believe that the mediating effect of company performance on the relationship between board diversity and CSR disclosure has not been investigated in prior literature. In essence, we argue that the effect of board diversity on CSR disclosure could be achieved more effectively through increasing company performance. Past studies have empirically proven that profitable companies were those that mostly disclosed CSR information (Haniffa and Cooke, 2005; Janggu et al., 2007; Scholtens, 2008; Menassa, 2010). Therefore, it is important to recognise the effect of company performance on the disclosure of CSR information.

Consistent with prior studies, we are taking the view from legitimacy theory, whereby companies disclose CSR information to show compliance with societal expectations (Newson and Deegan, 2002). Companies should be aware that society has the power to negatively affect, even terminate, their business operations (Janggu et al., 2007). The awareness about demands from the diverse society segments is better if the BOD is also diverse. Monitoring the legitimacy gap between companies and stakeholders by disclosing CSR information (Wallen and Wasserfaller, 2008) is the responsibility of the BOD. Consistent with the upper 
echelon theory (Hambrick and Mason, 1984), director's demographic factors are expected to be important to company's strategic choices and performance. In addition to these perspectives, we are motivated to contribute to the literature by injecting diversity perspective into upper echelon theory. We bring in diversity perspective which has been predominantly studied in social, organizational and management fields. Nevertheless, results in prior literature are mixed and inconclusive regarding the diversity-performance relationship and more research is needed in this area. While diversity increases creativity and innovative ideas in teams, diversity could result in increased conflict, less commitment and cohesion among team members (McLeod et al. 1996; McGrath et al., 2000). As such, deviating from prior literature, we venture into examining the effect of diversity in the BOD on one particular case of disclosure i.e. CSR disclosure. To date, not much is understood on the effect of diverse BOD measures (including gender, age, tenure, educational level, professional membership and functional background) on information disclosure and we address this void in this paper. Most prior literature that focused on understanding the role of each of these factors on either company's performance or information disclosure have neglected the effect of diversity of each factor. ${ }^{1}$ To this end, we believe our study could shed some light on the BOD diversity perspectives and their impact on performance and information disclosure. This study is significant as it is capable of revealing which form of board diversity that can influence company's financial performance and CSR information disclosure.

Malaysia is selected as a case to study this issue based on several grounds. First, as part of developing countries, the increase in CSR disclosure has been tremendous (as compared with other developing and developed countries). As described above, the increase could come from external pressure i.e. mandatory requirement of disclosure or internal pressure such as from the board of directors, which become the focus of this study. Second, Malaysia has been considered as a country with strong cultural resistance. Appointment of female directors to just to fulfill positions and meet the target quota may not be a good strategy to improve performance (Low et al., 2015) and disclosure. Malaysia is also among the first country that introduced a quota for women on board (Kent Baker et al., 2020).

This paper is organised as follows. The subsequent section provides the theoretical framework, develops the hypotheses while at the same time reviews the relevant empirical studies on board diversity, a company's financial performance and CSR information disclosure. Then, the research methodology will be explained and followed by a section on the results and data analysis. The final section contains the conclusion, discussion, research limitations, and future research recommendations.

\section{THEORY, LITERATURE AND HYPOTHESES}

Diversity refers to the heterogeneity, dissimilarity or dispersion (in short, for the purpose of this study, differences) in the composition of a group of people, often teams, in terms of demographic, values, skills or psychological attributes (Harrison and Klein, 2007; Li et al., 2018). While diversity may have positive effects such as increased integrative insights, creativity and more innovative ideas, it may also be detrimental to companies when conflicts arise among the members (McLeod et al., 1996; McGrath et al., 2000). The effect of diverse team members especially the BOD in companies, may also contingent on other important

\footnotetext{
1 Abdul Wahab et al. (2018) provide analysis of the effect of the board's diversity in age, tenure and education on book-tax difference in Malaysia using psychological and socially inspired upper echelon theory.
} 
aspects such as leadership styles, and members' attitudes towards diversity (Wegge et al., 2008; Van Knippenberg et al., 2013).

Diversity as a construct can be viewed as separation, variety or disparity functions within an organization (Harrison and Klein, 2007). First, diversity as separation. Adapted from theories of similarity attraction (Byrne, 1971) and social categorization (Tafjel, 1981; Turner, 1985), diversity may limit integration and raises conflicts. Here it promotes separation. Second, diversity as variety. This view uses argument from ecological and cognitive models of variation (Campbell, 1960), information processing or cybernetic theory (Ashby, 1956), that diversity may enrich the supply of information, ideas and improve decision making. Third, diversity as disparity function. This is based on distributive justice theory (Adams, 1963; Deutsch, 1985), tournament theory (Lazear and Rosen, 1981) and stratification status theory (Blau, 1960) which refer to diversity in prestige or power within the group that may affect internal competition and reduced the quality of communication. We examine our data using the second type i.e. between unit variance in the amounts of within unit diversity. The first and third views are regarded as competing explanations to the results. Therefore, in this study, diversity is viewed as "composition of differences in kind, source, or category of relevant knowledge or experience among all unit members..." (Harrison and Klein, 1997, page 1203). Here, we predict "uniform distribution with even spread of members across all possible categories of variety." (Harrison and Klein, 1997).

Based on variety argument, we test whether diversity and company performance can affect disclosure. Companies' performance can be represented by its turnover, productivity, financial (including profit), market, employee, innovation, or employee relations (Tseng and Lee, 2009). As management decides in which direction an organisation should go (Anthony and Govindarajan, 2007), the board of directors becomes the monitoring mechanism for corporate policy, and approving strategic plans (Chobpichien et al., 2008) to achieve financial and social performance. Since CSR disclosure initiative is very much driven by company's management, it is wise to study board demographic diversity factor that might contribute to the decision.

Huse et al. (2009) have argued that the quality of a board's decision will be higher if the members have diversity in terms of knowledge and expertise compared to decisions made by people with homogeneous backgrounds. Different backgrounds create a unique package an organisation can use to develop an innovative business strategy, new innovations and a comprehensive mission and vision that potentially can enhance the company's financial performance. The diverse knowledge gained from the members' education and work experience that is blended into a board's discussion could positively affect a company's performance and its CSR disclosure. Consistent with the above argument, the prior literature found that there is a positive relationship between highly educated workers who are diverse in their educational background and the likelihood to innovate (Østergaard et al., 2011). It is expected that members of a board of directors (BOD) will share their diverse knowledge through board discussion (Huse et al., 2009) and this knowledge can be converted into new products, processes and services, which will enhance the company's financial performance (Jiang and Li, 2008).

The argument based on variety perspective is actually jives with Slack Resources Theory. Past studies have proven a positive relationship between corporate financial performance (CFP) and corporate social performance (CSP) under the slack resources theory (Waddock and Graves, 1997; Orlitzky et al. 2003; Fauzi and Idris, 2009). Companies with strong financial performance may have better opportunities to invest in innovative projects 
that increase the companies' CSP (Waddock and Graves, 1997; Scholtens, 2008), which leads to better disclosure of CSR information (Belkaoui and Karpik, 1989). This study regards slack resources as extra resources that companies uses invest in any innovation projects that might bring a good reputation and enhance long-term performance, as well as improve their CSR activities (Abdul Rashid and Ibrahim, 2002; Elias, 2004) and CSR information disclosure (Van der Laan Smith et al., 2010). Similarly, the diversity may also be viewed as resources that a company has in terms of richness of idea which may affect financial performance and CSR disclosure positively. The relationship between board demographic diversity and financial performance also consistent with Upper Echelon Theory proposed by Hambrick and Mason (1984). This study extends our understanding by establishing relationship between diversity of demographic factors and disclosure of information. This relathionship can be explained by legitimacy theory that companies' disclosure is managed in a way to meet societal expectations (Newson and Deegan, 2002). Therefore, the research framework is suggested as Figure 1.

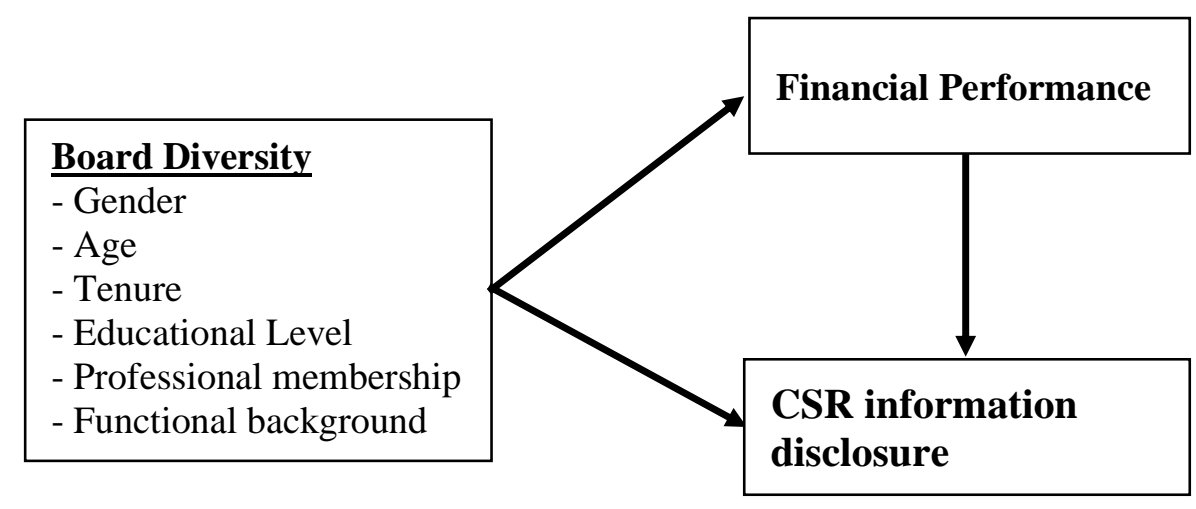

Figure 1: Research framework

\section{Diversity and Performance}

Past studies suggest that female directors influence board decision and hence financial performance by introducing more creative and innovative ideas (McInerny-Lacomb et al., 2008; Huse et al., 2009; Faes et al., 2010), lead to rational decision (McColl-Kennedy and Anderson, 2005) and avoid overaggressive (less risk taking) decision making (Lepine et al., 2002), which might be harmful to the company. It is also expected that a board consisting of young and old directors will be more effective in exchanging their strategies and ideas during board discussions. The older directors are mature and confident in making business strategies (Cheng et al., 2010) while the young directors produce more new innovative ideas that can be transformed into business strategies that might influence company performance (Cheng et al., 2010). However, a board with long tenure members can become homogeneous due to their close working relationship. It has been acknowledged that the close working relationship may give opportunities to the board directors to exchange knowledge, expertise, skills, talents, and experiences and the directors can contribute to sound business strategies based on their indepth industry knowledge and experiences in the company (Hambrick and Mason, 1984; He, 2008). Nevertheless, the role of shorter tenure directors should not be undermined. Shorter tenure directors are still fresh as board members and might have high enthusiasm, trying to prove to the board members that they have the ability to manage the company. The 
combination of experience from the longer tenure and enthusiasm from short tenure directors is expected to enhance a company's financial performance.

Cheng et al. (2010) advocated that a chairman's demographic background (i.e. educational level) significantly influenced financial performance. Prior literature found that competent directors (not necessarily their education level) increase shareholder value and performance because they have better information about the quality of projects (Wagner et al., 2009), knowledge and expertise (Barringer et al., 2005) and prior knowledge important in recognising opportunities (Sambasivan et al., 2009). Thus far, investigation into the influence of directors' diversity in terms of educational level on company's performance is lacking. It is expected that a board with a higher educational diversity would lead to better performance. A director who is a member of a professional body is expected to have more social capital than non-members. A mixture of professionals (for examples, accountant, lawyer, engineers or others, depending on the needs of the company) on a board could be better because they will have wider range of experience, way of thinking or techniques to solve problems (Huse et al., 2009) and subsequently change ideas into innovation, and that innovation might impact the company's performance positively (Jiménez-Jiménez and SanzValle, 2011). Functional areas of the board and top management team which include marketing, research and development, production, engineering, accounting, law, and finance (Jiang and Li, 2008) could affect firm performance (Hambrick and Mason, 1984). Therefore, diversity in functional background is also expected to enhance a company's financial performance.

Based on the above discussion, the first hypothesis is as follow:

H1: Each board diversity factor i.e. (a) gender, (b) age, (c) tenure, (d) educational level, (e) professional membership and (f) functional background is positively related to company's financial performance.

\section{Diversity and CSR information disclosure}

In line with diversity will bring in variety explanation, this study expects that board gender (Barako and Brown, 2008; Carter et al., 2007), age (Dusuki and Yusof, 2008; Post et al., 2011), tenure (Finkelstein and Hambrick, 1990; Kruger, 2010; Harjoto et al., 2015), educational level (Abdul Rashid and Ibrahim, 2002; Chobpichien et al., 2008; Elias, 2004; Dusuki and Yusof, 2008; Post et al. 2011), professional membership (Chobpichien et al., 2008; Janggu et al., 2014) and functional background diversity (McInerny-Lacomb et al., 2008; Huse et al., 2009; Faes et al., 2010) can increase CSR information disclosure. This expectation is guided by the argument that greater diversity means more diversity in terms of knowledge, values, perception, intention and preference.

Hence, this study has developed a second hypothesis as follow:

H2 (a): Each board diversity factor i.e. (a) gender, (b) age, (c) tenure, (d) educational level, (e) professional membership and (f) functional background is positively related to CSR information disclosure.

Financial Performance-CSR Information Disclosure 
Past studies revealed profitable companies report their corporate social responsibility activities in their annual reports (Gul and Leung, 2004; Haniffa and Cooke, 2005; Mohd Ghazali and Weetman, 2006; Janggu et al., 2007; Chobpichien et al., 2008; Menassa, 2010; Yusoff et al., 2013). This evidence is supported by the slack resources theory, whereby big companies spend money to disclose CSR information to reduce agency cost (Wallen and Wasserfaller, 2008), to legitimate their business activities (Newson and Deegan, 2002), or support long-term performance (Abdul Rashid and Ibrahim, 2002; Elias, 2004). As such, this study believes that a company's financial performance will enhance CSR information disclosure. Hence this study has formed the hypothesis of: disclosure.

H3: Company's financial performance is positively related to CSR information

\section{RESEARCH METHODOLOGY}

This is a cross-sectional study of non-financial Malaysian listed companies for the year 2009 . The year was selected since it is after financial subprime crisis that can affect company performance. The selected year is also after corporate governance code revision in 2007 but before the new corporate governance blueprint issued by the Securities Commission in 2012 that have significant effect on corporate governance practices in terms of composition of the board and its relationships. Later, sustainability reporting which include economic, environment, and social aspects was made mandatory by Bursa Malaysia in 2015. As such, in order to provide sufficient variability in the data, a period before 2015 was selected. In examining the relationship between board diversity and a company's financial performance, this study referred to the studies by Bear et al. (2010), Kim and Lim (2010), Talke et al. (2010), and Rivas (2012). This study uses the Blau's index (1977) to measure heterogeneity in board. This study also referred to the work of Carter et al. (2007), Adams and Ferreira (2009), and Abdullah and $\mathrm{Ku}$ Ismail (2013), that have examined the relationship between gender diversity and financial performance.

To measure CSR information disclosure, this study began with a pilot study. Fourteen listed companies were selected randomly that represent each sector in Malaysia. A CSR disclosure index consisting of 87 items at first, which combined the CSR index disclosure designed by Haniffa and Cooke (2005), Nik Ahmad and Sulaiman (2004), Mohd Ghazali and Weetman (2006), Barako and Brown (2008), and Post et al. (2011). The 2009 annual reports were read thoroughly and checked for every single item of the CSR index disclosure. Each observed disclosure was assigned a tick. After checking all the companies, the study eliminated 42 unticked items because they were not being practiced in Malaysia in 2009.

Hence, the study used 45 items (See Appendix A) to check for every single occurance of the companies' CSR information disclosure. A dichotomous procedure was applied in which the item scored 1 if it was disclosed, and 0 if the item was not disclosed. The score of each item was added to get the total disclosure score for each company. This total score was divided by the maximum possible score (45) to get the disclosure index:-

$$
C S D I_{j}=\frac{\sum^{n j} X_{i j}}{n j}
$$

where, 
$C S D I_{j}=$ corporate social disclosure index

$n j \quad=$ number of maximum items expected applicable for $j$ th firm, $n j \leq 45$

$X_{i j} \quad=0$ if $i$ th item not disclosed

The sample was selected randomly across all non-financial companies listed in the Bursa Malaysia for the year 2009. We purposely select this year based on several reasons. First, year 2009 was the first year of Malaysian Code on Corporate Governance (MCCG) 2007 revised version, while considering year 2008 as transition year. The revision strengthens the roles and responsibilities of the board of directors, audit committee and the internal audit function as compared to the previous version in year 2000. Secondly, when MCCG was revised again in 2012, board structure and composition were strengthened and directors are recognised as active and responsible fiduciaries (MCCG, 2012). The new MCCG 2012 also introduced cap on director's tenure to 9 years and suggestion on the balance of power between independent and non-independent directors. More stringent requirements are introduced in the latest 2017 version of MCCG such as introducing a minimum level of $30 \%$ of women on board for large companies. While it is interesting to see the dynamic of corporate governance requirements and its impact post revision year, the newly introduced requirements may also reduce the variation of diversity within the board. This could affect the study to a great extent.

Data was collected from the companies' annual reports on the Bursa Malaysia website. Random sampling was applied to make sure the results could be generalised to the population (Hair et al., 2007). In determining the sample size, this study adopted the formula applied by Godden (2004). ${ }^{\text {i }}$ Therefore, a sample of 270 companies were selected and fairly representing all industries i.e. construction, consumer products, hotels, infrastructure, industrial products, mining, properties, plantation, technology, and trading/services. Only companies with a complete set of data including all variables were selected as part of the sample. For the multivariate outliers, Mahalanobis distance has been applied. From the findings, there were companies with multivariate outliers that exceed 20.515 value and thus, omitted. There were companies with univariate outliers and missing data (mostly company age). For these reasons 65 companies were excluded from the sample because they might distort the result. Therefore, the final sample for analysis is 205 .

For the independent variables, the directors' background (i.e. the independent variables) data was obtained from the PLCs' annual reports under the Director's Profile. The financial data used for company financial performance were retrieved from the financial database, Osiris, and were double checked with the corresponding annual report. The items for CSR disclosure index were obtained by reading thoroughly through each entire annual report (Haniffa and Cooke, 2005) searching especially under the Chairman's Statement, Financial Statements, Director's Report in the form of narrative information (Muhammad Jamil et al., 2002) and under the CSR statement.

GENDER refers to the proportion of female directors (in percentage) to the total directors on board (Carter et al., 2007; Adams and Ferreira, 2009; Abdullah and Ku Ismail, 2013). AGE refers to the average of board members' ages. Then, the standard deviation was determined, based on the mean and later, the coefficient of variation was calculated. Board tenure (TENURE) represents skill and expertise development and is measured by averaging all directors' tenure years for each company. The coefficient of variation was also calculated. Director's education (EDU) indicates the highest education level each board director achieved i.e. undergraduate (i.e. bachelor's degree), or postgraduate (i.e. master's degree, doctoral degree). Professional membership title (PROFMEM) has been identified to be 
divided into four categories: lawyer, accountant, engineer, and others (Abdullah and $\mathrm{Ku}$ Ismail, 2013). If the company has no directors that fall into any of these categories, or all directors have the same professional titles, then the value equals zero (Kim and Lim, 2010). Director's functional background (FUNCTIONAL) was assessed through the function/area the director works. In this study the eleven functions/areas were accounting/finance, information system, customer service, human resources, sales and marketing, engineering, purchasing/procurement, legal and operations, management, production technical (R\&D), and other. Many researchers who studied group heterogeneity (Bear, 2010; Kim and Lim, 2010; Talke et al., 2010; Chau and Gray, 2010; Rivas, 2012) have used the Blau's index (1977) to measure diversity. Therefore, Blau's index is used to measure the estimation degree of team heterogeneity with respect to directors' education $(E D U)$, professional membership $(P R O F M E M)$ and and their functional areas (FUNCTIONAL) variables. ${ }^{\text {ii }}$ The index scores theoretically range from 0 to 0.80 (Richard et al., 2004).

This study includes some control variables that are predicted to be significant in influencing the CSR information disclosure and company's financial performance according to past studies. Control variables included in this study were CEO duality, board size, company age, company size, leverage, audit quality and industries.

Following are the regression equations that were applied in this study. The first equation is used to determine the relationship between the independent variables (gender, age, tenure, educational level, professional membership and functional background) and the dependent variable (company financial performance). The second equation is used to determine the relationship between the independent variables (gender, age, tenure, educational level, professional membership and functional background) and the dependent variable (CSR information disclosure). The third equation is used to determine the relationship between the company's financial performance and CSR information disclosure.

The equations are:

$$
\begin{aligned}
& \mathrm{CFP}=\beta_{0}+\beta_{1} \text { GENDER }_{i}+\beta_{2} \text { AGECV }_{i}+\beta_{3} \text { BDTCV }_{i}+\beta_{4} \text { EDU }_{i}+\beta_{5} \text { PROFMEM }_{i}+ \\
& \beta_{6} \text { FUNCTION }_{i}+\beta_{7} \text { DUALITY }_{i}+\beta_{8} \text { BDSIZE }_{i}+\beta_{9} \text { COMPAGE }_{i}+\beta_{10} \text { COMPSIZE }_{i}+ \\
& \beta_{11} D_{\text {DETEQUITY }}+\beta_{12} \text { AUDITQ }_{i}+\sum_{1}^{9} I N D+ \\
& \epsilon i
\end{aligned}
$$

$\mathrm{CSRDISC}=\beta_{0}+\beta_{1}$ CHROA $_{i}+\beta_{2}$ DUALITY $_{i}+\beta_{3}$ BDSIZE $_{i}+\beta_{4}$ COMPAGE $_{i}+$ $\beta_{5}$ COMPSIZE $_{i}+\beta_{6}$ DEBTEQUITY $_{i}+\beta_{7}$ AUDITQ $_{i}+\sum_{1}^{9} I N D+\varepsilon i$

where, 
$C F P=$ a company's financial performance as measured by changes in ROA for each company

CSRDISC $=$ corporate social disclosure index

$G E N D E R=$ proportion of female directors to male directors in a company's board

$A G E C V=$ coefficient of variance for age of directors in a company's board

$B D T C V=$ coefficient of variance for tenure of directors in a company's board

$E D U=$ Blau's index of board of director's educational level

PROFMEM = Blau's index of board of director's professional membership

$F U N C T I O N=$ Blau's index of board of director's functional background

DUALITY = chairperson with multiple directorships on board, 1 = board contains chairperson with multiple directorships and $0=$ otherwise

$B D S I Z E=$ natural log of directors on board

COMPAGE = age of the company at year 2009

COMPSIZE = size of company based on log value of total assets

$D E B T E Q U I T Y=$ ratio of total equity to debts

$A U D I T Q=1$ if type of audit firm is Big 4; otherwise $=0$

$I N D=$ ten type of industries

$\beta_{0, \ldots \ldots .,} \beta_{12}=$ coefficients

$\epsilon=$ disturbance term

$i=$ company

\section{FINDINGS AND DISCUSSION}

Table 1 presents the average of changes in ROA (CHROA) recorded a decrease by $155 \%$, average of companies disclosed 16\% level of CSR information (CSRDISC), and about $18 \%$ of board members are female directors which is still far from the target of $30 \%$. The distribution of firms across industries, in general, resembles the distribution of the population of listed companies.

A multicollinearity test has been done on the independent variables to find the correlations among them and the findings show, there is no VIF value that exceeds 10 . Therefore, multicollinearity is not a serious problem. Table 2 shows the highest correlation is between company's size and audit quality (33.2\%) i.e. larger companies have greater probability to hire 'Big 4' audit firms. There is a positive correlation between functional background and board size (23\%), which as expected. There is also positive correlation between functional background diversity and changes in ROA (15.9\%), as predicted in this study. 
Table 1: Descriptive statistics

\begin{tabular}{lrrrrrr}
\hline \multicolumn{1}{c}{ Variable } & Mean & Median & Mode & $\begin{array}{c}\text { Std. } \\
\text { Deviation }\end{array}$ & \multicolumn{1}{c}{ Min } & \multicolumn{1}{c}{ Max } \\
\hline GENDER & 0.087 & 0.000 & 0.000 & 0.100 & 0.000 & 0.400 \\
AGECV & 0.180 & 0.171 & 0.075 & 0.063 & 0.037 & 0.332 \\
BDTCV & 0.556 & 0.555 & 0.000 & 0.283 & 0.000 & 1.488 \\
EDU & 0.568 & 0.611 & 0.611 & 0.124 & 0.219 & 0.861 \\
PROFMEM & 0.500 & 0.500 & 0.571 & 0.153 & 0.165 & 0.917 \\
FUNCTION & 0.648 & 0.660 & 0.667 & 0.096 & 0.406 & 0.816 \\
CSRDISC & 0.162 & 0.133 & 0.067 & 0.111 & 0.022 & 0.444 \\
CHROA & -1.547 & -0.570 & 0.340 & 8.342 & -41.240 & 28.750 \\
DUALITY & 0.112 & 0.000 & 0.000 & 0.316 & 0.000 & 1.000 \\
BDSIZE & 1.972 & 1.946 & 1.946 & 0.246 & 1.386 & 2.890 \\
COMPAGE & 12.516 & 12.000 & 23.000 & 7.684 & 0.300 & 49.000 \\
COMPSIZE & 5.420 & 5.389 & 3.243 & 0.642 & 3.243 & 7.570 \\
DEBTEQUITY & 1.118 & 0.651 & -1.635 & 2.511 & -1.635 & 28.805 \\
AUDITQ & 0.541 & 1.000 & 1.000 & 0.499 & 0.000 & 1.000 \\
\hline
\end{tabular}


Table 2: Pearson correlations among variables

\begin{tabular}{|c|c|c|c|c|c|c|c|c|c|c|c|c|c|c|c|}
\hline & Variable & 1 & 2 & 3 & 4 & 5 & 6 & 7 & 8 & 9 & 10 & 11 & 12 & 13 & 14 \\
\hline 1 & CSRDISC & 1.000 & -0.067 & -0.069 & 0.127 & -0.046 & 0.070 & 0.078 & 0.059 & 0.102 & 0.097 & 0.099 & 0.315 & -0.019 & 0.155 \\
\hline 2 & GENDER & & 1.000 & 0.186 & -0.110 & -0.036 & 0.050 & 0.063 & 0.110 & 0.035 & -0.047 & 0.076 & 0.006 & -0.056 & -0.038 \\
\hline 3 & $A G E C V$ & & & 1.000 & -0.151 & 0.145 & -0.079 & -0.008 & 0.074 & 0.046 & -0.077 & -0.034 & -0.062 & -0.002 & -0.018 \\
\hline 4 & PROFMEM & & & & & -0.066 & 0.079 & 0.016 & -0.081 & -0.035 & 0.067 & -0.040 & 0.092 & 0.045 & 0.036 \\
\hline 5 & FUNCTION & & & & & 1.000 & -0.097 & 0.012 & 0.056 & 0.230 & -0.294 & 0.159 & -0.114 & 0.019 & 0.002 \\
\hline 6 & $B D T C V$ & & & & & & 1.000 & -0.040 & -0.065 & 0.051 & 0.325 & -0.133 & 0.170 & 0.101 & 0.050 \\
\hline 7 & $E D U$ & & & & & & & 1.000 & 0.043 & 0.144 & 0.007 & 0.015 & 0.072 & 0.062 & -0.010 \\
\hline 8 & DUALITY & & & & & & & & 1.000 & 0.026 & -0.206 & 0.001 & -0.109 & -0.060 & -0.027 \\
\hline 9 & BDSIZE & & & & & & & & & 1.000 & 0.064 & 0.047 & 0.339 & 0.036 & 0.143 \\
\hline 10 & COMPAGE & & & & & & & & & & 1.000 & 0.053 & 0.371 & -0.006 & 0.135 \\
\hline 11 & CHROA & & & & & & & & & & & 1.000 & 0.064 & 0.118 & 0.058 \\
\hline 12 & COMPSIZE & & & & & & & & & & & & 1.000 & 0.207 & 0.332 \\
\hline 13 & DEBTEQUITY & & & & & & & & & & & & & 1.000 & 0.041 \\
\hline 14 & $A U D I T Q$ & & & & & & & & & & & & & & 1.000 \\
\hline
\end{tabular}

\begin{tabular}{|c|c|c|c|c|c|}
\hline Note: & & & & & \\
\hline CSRDISC & $=$ & CSR disclosure index & DUALITY & $=$ & duality \\
\hline GENDER & $=$ & Gender & $B D S I Z E$ & $=$ & Board size \\
\hline$A G E C V$ & $=$ & Age coefficient of variance & COMPAGE & $=$ & Company's age \\
\hline PROFMEM & $=$ & Professional membership & CHROA & $=$ & Changes in $R O A$ \\
\hline FUNCTION & $=$ & Functional background & COMPSIZE & $=$ & Company's size \\
\hline$B D T C V$ & $=$ & $\begin{array}{l}\text { Board tenure coefficient of } \\
\text { variance }\end{array}$ & DEBTEQUITY & $=$ & Debt to equity \\
\hline$E D U$ & $=$ & Educational level & $A U D I T Q$ & $=$ & Audit quality \\
\hline
\end{tabular}


Hypothesis 1 tests the relationship between board diversity (of which the characteristcs are gender, age, tenure, educational level, professional membership, and functional background) and the company's financial performance represented by change in return on assets (CHROA).

Table 3: Regression analysis among variables for testing Hypothesis 1 and 2

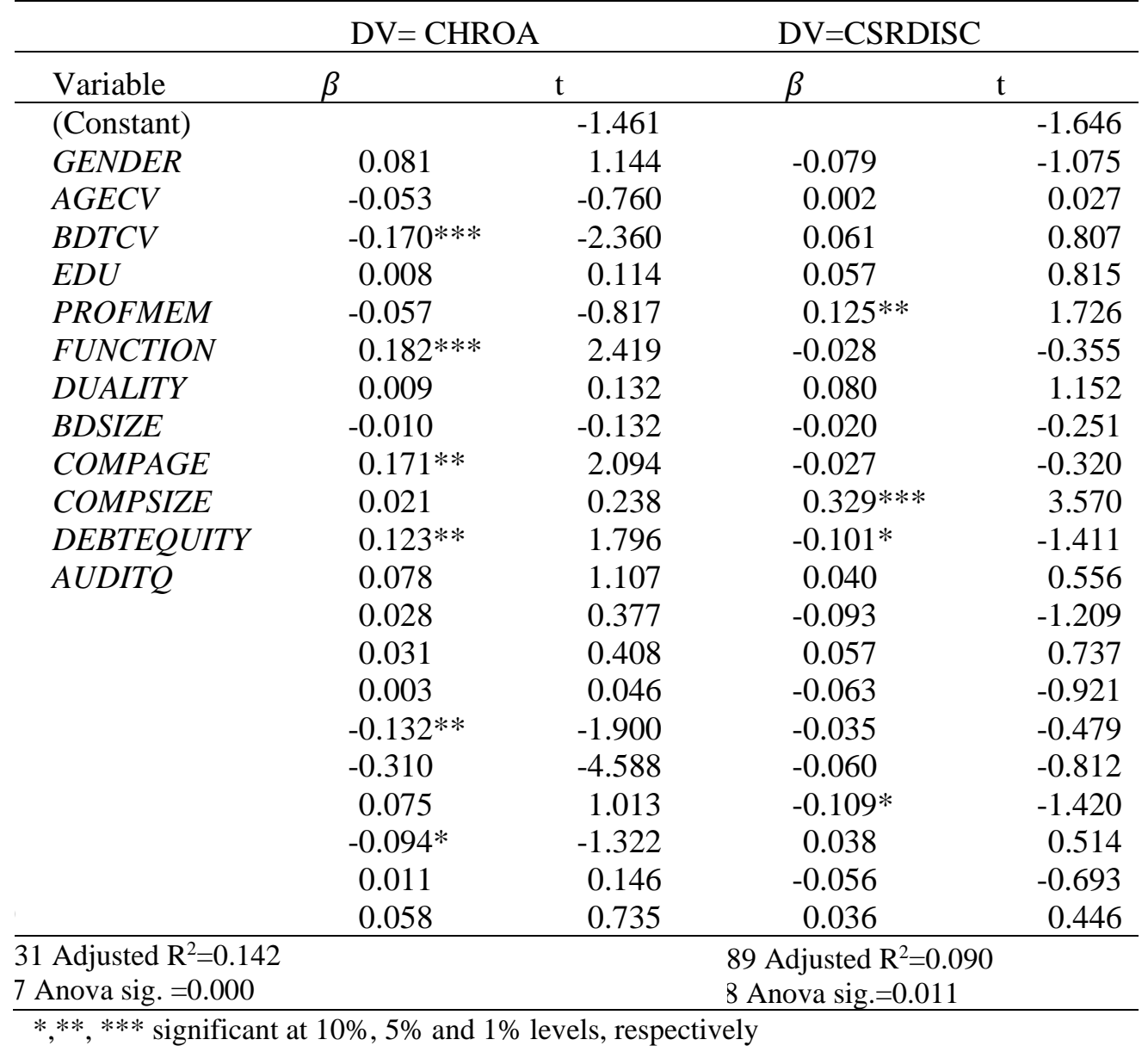

This study found that functional background is significantly related to a company's financial performance at $\mathrm{p}<0.01$. This result shows that functional background diversity is important in increasing a company's financial performance. This finding seems to be consistent with Hambrick and Mason (1984) which posits that board characteristics can predict organisational outcomes. Board tenure diversity was found to be significant at $\mathrm{p}<0.01$, but in a negative direction. It seems that the as the board tenure becomes more diverse, the ROA will derail.

Control variables such as the company's age and debt to equity ratio were found to be significantly related to changes in ROA at $\mathrm{p}<0.05$. This finding indicates that the older the company, and the higher the leverage, the better its performance. The model was significant at the 0.000 level and the $\mathrm{R}^{2}$ was 0.231 . Contrary to expectations, this study did not find a significant relationship for gender, age, education, and professional membership diversity. 
Gender diversity was found not to be related to company's financial performance. This finding is consistent with past studies (Marinova et al., 2010; Abdullah and $\mathrm{Ku}$ Ismail, 2013; Rachagan et al., 2014). Abdullah and Ku Ismail (2013) explained that having females in top management among Malaysian corporations is still new. This study agrees with Abdullah and $\mathrm{Ku}$ Ismail (2013), because there was only $8.7 \%$ gender diversity on the Malaysian corporate boards. The insufficient number of female directors (at least three) was not enough to influence board decision making (Post et al., 2011; Joecks et al., 2013). The majority of males, who can be more aggressive compared to females, can dominate board discussions. The aggressiveness of male directors might generate a feeling of inferiority among the female directors or hinder females from fully participating in board discussions. However, this reason is subject to investigation utilising a different theoretical framework.

We did not find any positive relationship between age diversity and a company's financial performance. This finding contradicts with the study by Hassan and Marimuthu (2016). In this study, the evidence shows that there is $18.2 \%$ age diversity among the Malaysian corporations. This percentage reflects that age among the directors on board is not adequately diverse. Past studies posit that young directors are innovative, risk takers and focus more on long term performance. A young director, however, might feel inadequate when dealing with the senior directors. The imbalance might distort an open board discussion. Many innovative ideas might be missed which could contribute to lower performance. At the same time, the senior directors may hold their positions, looking for short term performance achievement as they get older (Abdullah and Ku Ismail, 2013).

In this study, board tenure diversity was found to be related to a company's financial performance. However, the relationship is in the opposite way. This finding is consistent with Cheng et al. (2010) which found that board tenure had a weak effect on most of the performance levels in their study. This study revealed that when board tenure diversity increased, the company's performance decreased. It is difficult to explain this finding, but it might be related to the directors' behaviour. Short tenure directors may find themselves struggling to enhance the company's performance for long term goals due to their lack of experience. However, the longer tenure directors who are already undertand the company inside out, may have less difficulty in enhancing company performance. However, this study did not examine the director's behaviour towards performance because it is outside the scope of study.

This study also did not find any significant relationship between educational diversity and a company's financial performance. The evidence shows that there was $56.8 \%$ of educational diversity. This shows that almost all of the Malaysian corporations are led by well educated directors and there are good combinations of educational levels on boards. However, the educational diversity was not important in determining the company's financial performance. This result does not contradict with the study by Rachagan et al. (2014). They found that a CEO's qualifications are positively related to the level of organizational commitment, which in turn mediates the relationship between the CEO's qualifications and the company's performance. Diversity in education may not lead to creative discussion, competitiveness, innovation, and strategic business decisions. Less educated directors may feel less able to influence the board discussion. However, this study did not investigate this effect because it is beyond the scope of this study. 
This study revealed that half of the Malaysian board members have professional membership, as the evidence shows $50 \%$ professional membership diversity. This study did not find any significant relationship between professional membership diversity and a company's financial performance. Consistent with Wu et al. (2007) those professional employees might feel reluctant to accept knowledge from other non-professionals because they feel they are higher achievers in their domains.

It is interesting to note that of all six variables in this study, functional background diversity most significantly enhanced financial performance. This finding is consistent with the prior studies that emphasized the importance of functional background in enhancing a company's financial performance (Barringer et al., 2005; Wu et al., 2007; Bennour and Crestani, 2007; Kim and Lim, 2010). The different functions of directors are expected to blend when there is strong integration among them. Board members are expected to communicate with each other and share their knowledge, skills, and experience in their functional areas to develop business strategies (Van Ees et al., 2008). Having diverse functional backgrounds, the board members may have different perspectives in discussions that lead to an increase in firm's financial performance (Huse et al., 2009; Faes et al., 2010).

Hypothesis 2 tests the impact of board diversity (of which the characteristics are gender, age, tenure, educational level, professional membership, and functional background) on CSR information disclosure, which is represented by the CSR information disclosure index score (CSRDISC).

Table 3 shows the relationship between the board diversity (in terms of gender, age, tenure, educational level, professional membership, and functional background) and CSR information disclosure. This study confirms that diversity in professional membership is positively related to CSR information disclosure (significant at $\mathrm{p}<0.05$ ). The finding enriches our understanding from previous study done by Chobpichien et al. (2008) that not only board members with a CPA qualification (professional membership) could influence voluntary disclosure, but diversity in professional membership could have an impact. This finding is consistent with the prior study by Janggu et al. (2014). A possible explanation for this might be that board members with professional memberships especially in law, engineering, and accounting, due to their training, have strong CSR perceptions (Kim and Reber, 2009). No significant relationship was found in gender, age, functional background, board tenure and educational diversity.

Hypothesis 3 tests the relationship between company's financial performance and CSR information disclosure. Table 4 shows that financial performance (represented by CHROA) is not significantly related to CSR information disclosure. This finding is consistent with prior studies (Post et al., 2011; Ahmed Haji and Mohd Ghazali, 2013). However, this result contradicts with the finding of Madi et al. (2013). Madi et al. used 146 Malaysian listed companies for the year 2006 before the economic recession of 2007. This current study is based on Malaysian listed companies in 2009, during a period of economic recovery. Therefore, listed companies in 2009 were cautious in taking on any costly projects, such as CSR information disclosure. They might have been concerned that any extra costs may reduce the next year's performance. This finding is supported by Arora and Dharwadkar (2011) who found that when a company's performance is bad, there will be no CSR investment as expected by the shareholders. The effect of good governance and CSR information disclosure depends on the level of slack resources (high or low). 
Furthermore, most of the government-linked companies (Said et al., 2009) and politically visible entities (Belkaoui and Karpik, 1989) disclosed CSR information, regardless of profit. The company's size, which was measured by the log value of total assets, was found to be positively related to CSR information disclosure. Thus, as the result indicates, big companies with excess free cash flow may have slack resources to disclose CSR information. However, this study did not directly investigate the government intervention effects and the companies' free cash flow as slack resources.

Table 4: Regression analysis among variables for testing Hypothesis 3

\begin{tabular}{lcr}
\hline Variable & Beta & \multicolumn{1}{c}{$\mathrm{t}$} \\
\hline (Constant) & & -1.443 \\
DUALITY & 0.073 & 1.055 \\
BDSIZE & -0.033 & -0.444 \\
COMPAGE & 0.014 & 0.179 \\
CHROA & 0.072 & 0.983 \\
COMPSIZE & $0.341^{* * * *}$ & 3.760 \\
DEBTEQUITY & -0.087 & -1.225 \\
AUDITQ & 0.044 & 0.608 \\
IND1 & -0.071 & -0.938 \\
IND2 & 0.036 & 0.473 \\
IND3 & -0.064 & -0.933 \\
IND4 & -0.028 & -0.395 \\
IND6 & -0.072 & -0.988 \\
IND7 & $-0.120 *$ & -1.602 \\
IND8 & 0.041 & 0.566 \\
IND9 & -0.045 & -0.607 \\
IND10 & 0.048 & 0.626 \\
\hline${ }^{2}=0.161$ Adjusted $\mathrm{R}^{2}=0.090$ & & \\
F=2.251 Anova sig. $=0.005$ & & \\
\hline
\end{tabular}

Additional analyses were conducted using stepwise regression to try to get a suitable combination of board diversity. This study used this procedure in which the independent variables (GENDER, AGECV, PROFMEM, FUNCTION, BDTCV, and EDU) were entered into the regression one by one. The result suggests that board diversity in functional background is important to influencing a company's financial performance (coefficient=13.846, $\mathrm{t}=2.29 \mathrm{p}<0.05$ ).

\section{CONCLUSIONS}

The objective of this paper is to investigate the role of board diversity (gender, age, professional membership, functional background, board tenure and educational diversity) and company performance on corporate social responsibility (CSR) disclosure. Board diversity could provide a different perspective on CSR information disclosure (Barako and Brown, 2008; Meriac et al., 2009; Post et al., 2011). Different gender roles (Singh and Vinnicombe, 2000; Lepine et al., 2002; McColl-Kennedy and Anderson, 2005) could encourage creative discussion (Huse et al., 2009; Faes et al., 2010) that leads to innovation (Østergaard et al., 
2011) and better business strategies (Kang et al., 2010). Hence, this study argues that board diversity may increase company's financial performance and CSR information disclosure.

The results revealed that most of the forms of board diversities did not have any relationship to CSR information disclosure, except for professional membership diversity. Those professionals who are expert in their jobs may have diverse CSR skills according to their respective disciplines that can be implemented by the business. These professional traits will become a strong motivation among the board members in influencing CSR information disclosure. This finding is consistent with the Bursa Malaysia CSR (2007) Status Report which advised Malaysian companies to have diversity in their board in order to improve CSR information disclosure levels.

This study found that functional background diversity is important to enhance company's financial performance. It can be implied that members from different functional backgrounds bring their competencies in specific areas into the board process and combine their industrial knowledge (theoretical and practical) with others (Bennour and Crestani, 2007).

These findings are consistent with the MCCG (Revised 2007) recommendations that emphasise diversity of board composition; that is, the board should be comprised of members with mixed skills, experience, education, expertise, and competencies to gain financial and social performance. Overall, this study revealed that functional background diversity can be a predictor of financial performance and professional membership diversity can be a predictor of CSR information disclosure of Malaysian companies. Hopefully, with this findings, companies see that it is beneficial to put more emphasis on ensuring board diversity in both functional background and professional membership.

The result implicitly suggests that not all diversity factors are aligned to "variety" explanation. Some diversity factors might be more aligned to "separation" and/or disparity function as suggested in Harrison and Klein (2007). Diversity in some factors may results in conflicts within an organization, or a combination of both. A comprehensive study that investigates these alternative explanations might be needed.

This study did not investigate any endogeneity problems that may arise, especially when regressing the relationship between company's financial performance and CSR information disclosure, due to data limitation. This study only applied linear regression, which may not show any causality effect among the variables (Tabachnick and Fidell, 2007). The other limitation of this study is about generalisation of the data set. This study only applies to a single year data set. The findings only give a picture of events in one year and may not be comparable to other years before or after the sample year.

This study also suggests future research to further investigate other perspectives of diversity typology i.e. diversity as separation and diversity as functional disparity. Feelings of inferiority that might affect the relationship between board diversity and financial performance and also the relationship between board diversity and CSR information disclosure. Inferiority in a certain member might hinder creative discussion among the board members with diversified backgrounds. Future research also can test the proportion of inside directors with long tenure to outside directors with long tenure, because evidence shows that inside directors with long tenure influence CSR (Kruger, 2010). 


\section{REFERENCES}

Abdullah, S.N. and Ku Ismail, K.N. (2013), "Gender, ethnic and age diversity of the boards of large Malaysian firms and performance", Jurnal Pengurusan, Vol. 38, pp. 27-40.

Abdul Rashid, M.Z. and Ibrahim, S. (2002), "Executive and management attitudes towards corporate social responsibility in Malaysia", Corporate Governance, Vol. 2 No. 4, pp. $10-16$.

Abdul Wahab, N.S ., Ntim, C.G., Mohd Adnan, M.M., Ling, T.Y. (2018). Top management team heterogeneity, governance changes and book-tax differences. Journal of International Accounting, Auditing and Taxation, Vol. 32, pp. 32-46.

Adams, C.A. (2002), "Internal organisational factors influencing corporate social and ethical reporting", Accounting, Auditing \& Accountability Journal, Vol. 15 No. 2, pp. 223250.

Adams, J. S. (1963), "Toward an understanding of inequity", Journal of Abnormal and Social Psychology, Vol. 67 No. 5, pp. 422-436.

Adams, R.B. and Ferreira, D. (2009), "Women in the boardroom and their impact on governance and performance", Journal of Financial Economics, Vol. 94 No. 2, pp. 291-309.

Ahmed Haji, A. and Mohd Ghazali, N.A. (2013), "Factors influencing corporate voluntary disclosures in Malaysia", International Journal of Managerial and Financial Accounting, Vol. 5 No. 4, pp. 327-349.

Anthony, R.N. and Govindarajan, V. (2007), Management Control System, Twelfth Edition, McGraw-Hill, New York.

Arora, P. and Dharwadkar, R. (2011), "Corporate governance and corporate social responsibility (CSR): The moderating roles of attainment discrepancy and organization slack", Corporate Governance: An International Review, Vol. 19 No. 2, pp. 136-152.

Ashby, W. R. 1956, An Introduction to Cybernetics, Wiley, New York.

Barako, D.G. and Brown, A.M. (2008), "Corporate social reporting and board representation : evidence from the Kenyan banking sector", Journal of Management \& Governance, Vol. 12 No. 4, pp. 309-324.

Barringer, B.R., Jones, F.F. and Neubaum, D.O. (2005). "A quantitative content analysis of the characteristics of rapid-growth firms and their founders", Journal of Business Venturing, Vol. 20 No. 5, pp. 663-687.

Bear, S., Rahman, N. and Post, C. (2010), "The impact of board diversity and gender composition on corporate social responsibility and firm reputation", Journal of Business Ethics, Vol. 97 No. 2, pp. 207-221. 
Belkaoui, A. and Karpik, G.P. (1989), "Determinants of the corporate decision to disclose social information", Accounting, Auditing \& Accountability Journal, Vol. 2 No. 1, pp. $36-51$.

Bennour, M. and Crestani, D. (2007), "Using competencies in performance estimation: From the activity to the process", Computers in Industry, Vol. 58 No. 2, pp. 151-163.

Blau, P. M. (1960), Patterns of deviation in work groups, Sociometry, Vol. 23 No. 3, pp. 245261.

Blau, P.M. (1977), Inequality and heterogeneity: a primitive theory of social structure, Free Press, New York.

Bursa Malaysia CSR 2007 status report, available at: http://www.bursamalaysia.com (accessed 25 June 2011).

Byrne, D. E. (1971), The attraction paradigm, Academic Press, New York.

Campbell, D. T. (1960), "Blind variation and selective retention in creative thought as in other knowledge processes", Psychological Review, Vol. 67 No. 6, pp. 380-400.

Carter, D.A., D'Souza, F.P., Simkins, B.J. and Simpson, W.G. (2007), "The diversity of corporate board committees and firm financial performance", Social Science Research

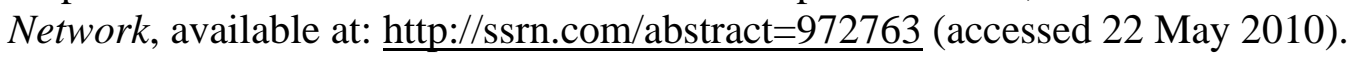

Chau, G. and Gray, J.S. (2010), "Family ownership, board independence and voluntary disclosure: Evidence from Hong Kong", Journal of International Accounting, Auditing and Taxation, Vol. 19 No. 2, pp. 93-109.

Cheng, L.T.W., Chan, R.Y.K. and Leung, T.Y. (2010), "Management demography and corporate performance: Evidence from China", International Business Review, Vol. 19 No. 3, pp. 261-275.

Chobpichien, J., Haron, H. and Ibrahim, D.N. (2008), "Corporate governance, executive directors and level of voluntary disclosure: The case of public listed companies in Thailand", Malaysian Management Journal, Vol. 12 No. 1\&2, pp. 17-70.

Deutsch, M. 1985. Distributive justice: A social psychological perspective, Yale University Press, New Haven.

Dusuki, A.W. and T.M. Yusof, T.F.M. (2008), "The pyramid of corporate social responsibility model: Empirical evidence from Malaysian stakeholder perspectives", Malaysian Accounting Review, Vol. 7 No. 2, pp. 29-54.

Elias, R.Z. (2004), "An examination of business students' perception of corporate social responsibilities before and after bankruptcies", Journal of Business Ethics, Vol. 52 No.3, pp. 267-281.

Faes, W., Swinnen, G. and Snellinx, R. (2010), "Gender influences on purchasing negotiation 
objectives, outcomes and communication patterns", Journal of Purchasing and Supply Management, Vol. 16 No. 2, pp. 88-98.

Fauzi, H. and Idris, K. M. (2009), "The relationship of CSR and financial performance: New evidence from Indonesian companies", Issues in Social and Environmental Accounting, Vol. 3 No. 1, pp. 66-87.

Finkelstein, S. and Hambrick, D.C. (1990), "Top-management-team tenure and organizational outcomes: The moderating role of managerial discretion", Administrative Science Quarterly, Vol. 35 No. 3, pp. 484-503.

Galbreath, J. (2009), "Building corporate social responsibility into strategy", European Business Review, Vol. 21 No. 2, pp. 109-127.

Gul, F.A. and Leung, S. (2004), "Board leadership, outside directors' expertise and voluntary corporate disclosures", Journal of Accounting and Public Policy, Vol. 23 No. 5, pp. 351-379.

Godden, B. (2004), Sample Size Formula, available at: http://williamgodden.com/samplesizeformula.pdf (accessed 8 March 2011).

Hair, J., Money, A., Page, M. and Samouel, P. (2007), Research Methods For Business. Wiley, USA.

Harjoto, M., Laksmana, I. and Lee, R. (2015), "Board diversity and corporate social responsibility", Journal of Business Ethics, Vol. 132 No. 4, pp. 641-660.

Harjoto,M. A., and Rossi, F. (2019). "Religiosity, female directors, and corporate social responsibility for Italian listed companies." Journal of Business Researh, Vol. 95 No. 1. pp. 338-346.

Hassan, R. and Marimuthu, M. (2016), "Corporate governance, board diversity, and firm value: Examining large companies using a panel data approach", Economics Bulletin, Vol. 36 No. 3, pp. 1737-1750.

Hambrick, D.C. and Mason, P.A. (1984), "Upper echelons: The organization as a reflection of its top managers", Academy of Management Review, Vol. 9 No. 2, pp. 193-206.

Haniffa, R.M. and Cooke, T.E. (2005), "The impact of culture and governance on corporate social reporting", Journal of Accounting and Public Policy, Vol. 24 No. 5, pp. 391430.

He, L. (2008), "Do founders matter? A study of executive compensation, governance structure and firm performance", Journal of Business Venturing, Vol. 23 No. 3, pp. 257-279.

Huse, M., Nielsen, S.T. and Hagen, I.M. (2009), "Women and employee-elected board members, and their contributions to board control tasks", Journal of Business Ethics, Vol. 89 No. 4, pp. 581-597. 
Janggu, T., Joseph, C. and Madi, N. (2007), "The current state of corporate social responsibility among industrial companies in Malaysia", Social Responsibility Journal, Vol. 3 No. 3, pp. 9-18.

Janggu, T., Darus, F., Mohamed Zain, M. and Sawani, Y. (2014), "Does good corporate governance lead to better sustainability reporting? An analysis using structural equation modeling", Procedia-Social and Behavioral Sciences, Vol. 145, pp. 138-145.

Jenkins, H. and Yakovleva, N. (2006), "Corporate social responsibility in the mining industry: Exploring trends in social and environmental disclosure", Journal of Cleaner Production, Vol. 14 No. 3-4, pp. 271-284.

Jensen, M.C. and Meckling, W.H. (1976), "Theory of the firm: Managerial behavior, agency costs and ownership structure", Journal of Financial Economics, Vol. 3 No. 4, pp. 305-360.

Jiang, X. and Li, Y. (2008), "The relationship between organizational learning and firms' financial performance in strategic alliances: A contingency approach", Journal of World Business, Vol. 43 No. 3, pp. 365-379.

Jiménez-Jiménez, D. and Sanz-Valle, R. (2011), "Innovation, organizational learning, and performance", Journal of Business Research, Vol. 64 No. 4, pp. 408-417.

Joecks, J., Pull, K. and Vetter, K. (2013), "Gender diversity in the boardroom and firm performance: What exactly constitutes a "Critical Mass?", Journal of Business Ethics, Vol. 118 No. 1, pp. 61-72.

Kang, E., Ding, D. K. and Charoenwong, C. (2010), "Investor reaction to women directors", Journal of Business Research, Vol. 63 No. 8, pp. 888-894.

Kaymak, T., and Bektas, E. (2017), "Corporate social responsibility and governance: Information disclosure in multinational corporations", Corporate Social Responsibility and Environmental Management, Vol. 24 No. 6, pp. 555-569.

Kent Baker, H., Pandey, N., Kumar, S., and Haldar, A. (2020). "A bibliometric analysis of board diversity: Current status, development, and future research directions," Journal of Business Research Vol. 108, pp. 232-246.

Kim, H. and Lim, C. (2010), "Diversity, outside directors and firm valuation: Korean evidence", Journal of Business Research, Vol. 63 No. 3, pp. 284-291.

Kim, S. and Reber, B. H. (2009), "How public relations professionalism influences corporate social responsibility: A survey of practitioners", Journalism \& Mass Communication Quarterly, Vol. 86 No. 1, pp. 157-174.

Kruger, P. (2010), "Corporate social responsibility and the board of directors", Working Paper (Job Market Paper), Toulouse School of Economics, Toulouse, 31 May 2010. 
Lazear, E.P. and Rosen, S. (1981), "Rank-order tournaments as optimum labor contracts", Journal of Political Economy, Vol. 89 No. 5, pp. 841-864.

Lepine, J.A., Hollenbeck, J.R., Ilgen, D.R., Colquitt, J. A. and Ellis, A. (2002), "Gender composition, situational strength, and team decision-making accuracy: A criterion decomposition approach", Organizational Behavior and Human Decision Processes, Vol. 88 No. 1, pp. 445-475.

Li, J., Meyer, B., Shemla, M., and Wegge, J. (2018), "From being diverse to becoming diverse: A dynamic team diversity theory", Journal of Organizational Behavior, Vol. 39 No. 8, pp. 956-970.

Lo, Y.P. (2018). CSR and the Sustainability reporting landscape of Malaysia <https://www.lh-ag.com/wp-content/uploads/2018/12/6-CSR-and-the-SustainabilityReporting-Landscape-of-Malaysia.pdf> Accessed 16 December 2019.

Low, D.C.M., Roberts, H. and Whiting, H. (2015). "Board gender diversity nad firm performance: Evidence from Hong Kong, South Korea, Malaysia and Singapore." Pacific Basin Finance Journal 35: 381-401.

Madi, H.K., Ishak, Z. and Abdul Manaf, N.A. (2013), "Audit committee characteristics and voluntary disclosure: Evidence from Malaysian listed firms", Terengganu International Finance and Economics Journal, Vol. 3 No. 1, pp. 14-21.

Marinova, J., Plantenga, J. and Remery, C. (2016), "Gender diversity and firm performance: evidence from Dutch and Danish boardrooms", The International Journal of Human Resource Management, Vol. 27 No.15, pp. 1777-1790.

Malaysian Code on Corporate Governance, revised (2007), available at: http://www.ecgi.org/codes/documents/cg_code_malaysia_2007_en.pdf (accessed 3 February 2011).

Malaysian Code on Corporate Governance (2016), available at: https://www.sc.com.my/wpcontent/uploads/eng/html/consultation/160418_PublicConsultation_2.pdf (accessed 16 December 2016).

McColl-Kennedy, J.R. and Anderson, R.D. (2005), "Subordinate-manager gender combination and perceived leadership style influence on emotions, self-esteem and organizational commitment", Journal of Business Research, Vol. 58 No. 2, pp. 115125.

McGrath, J., Arrow, H. and Berdahl, J. (2000), "The study of groups: Past, present and future", Personality and Social Psychology Review, Vol. 4 No. 1, pp. 95-105.

McLeod, P.L., Lobel, S.A. and Cox, T.H. (1996), "Ethnic diversity and creativity in small groups", Small Group Research, Vol. 27 No. 2, pp. 248-264. 
Md Nor, H., Mohd Saleh, N., Jaffar, R. and Abdul Shukor, Z. (2010), "Corporate governance and R\&D reporting in Malaysian MESDAQ market", Int. Journal of Economics and Management, Vol. 4 No. 2, pp. 350-372.

Menassa, E. (2010), "Corporate social responsibility. An exploratory study of the quality and extent commercial banks", Journal of Applied Accounting Research, Vol. 11 No. 1, pp. 4-23.

Meriac, J.P., Poling, T.L. and Woehr, D.J. (2009), "Are there gender differences in work ethic? An examination of the measurement equivalence of the multidimensional work ethic profile", Personality and Individual Differences, Vol. 47 No. 3, pp. 209-213.

Mohamed Zain, M. and Janggu, T. (2006), "Corporate social disclosure (CSD) of construction companies in Malaysia", Malaysian Accounting Review, Vol. 5 No. 1, pp. 85-114.

Mohd Ghazali, N.A. and Weetman, P. (2006), "Perpetuating traditional influences: Voluntary disclosure in Malaysia following the economic crisis", Journal of International Accounting, Auditing and Taxation, Vol. 15 No. 2, pp. 226-248.

Muhammad Jamil, C.Z., Alwi, K. and Mohamed, R. (2002), "Corporate social responsibilty disclosure in the annual reports of Malaysian companies: A longitudinal study", Social and Environmental Accounting Journal, Vol. 22 No. 2, pp. 5-9.

Mun, E., and Jung, J. (2018), "Change above the glass ceiling: Corporate social responsibility and gender diversity in Japanese firms", Administrative Science Quarterly, Vol. 63 No. 2, pp. 409-440.

Newson, M. and Deegan, C. (2002), "Global expectations and their association with corporate social disclosure practices in Australia, Singapore, and South Korea", International Journal of Accounting, Vol. 37 No. 2, pp. 183-213.

Nik Ahmad, N.N. and Sulaiman, M. (2004), "Environment disclosure in Malaysia annual reports: A legitimacy theory perspective", IIUM International Journal of Commerce and Management, Vol. 14 No. 1, pp. 44-58.

Orlitzky, M., Schmidt, F.L., and Rynes, S.L. (2003), "Corporate social and financial performance: A meta-analysis", Organization Studies, Vol. 24 No. 3, pp. 403-441.

Østergaard, C.R., Timmermans, B. and Kristinsson, K. (2011), "Does a different view create something new? The effect of employee diversity on innovation", Research Policy, Vol. 40 No. 3, pp. 500-509.

Post, C., Rahman, N. and Rubow, E. (2011), "Green governance: Boards of directors' composition and environmental corporate social responsibility", Business \& Society, Vol. 50 No. 1, pp. 189-223.

Rachagan, S., Tong, J.L.Y., Terpstra, R. and Mahenthiran, S. (2014), "CEOs organizational commitment and firm performance: Malaysian evidence", International Business and 
Management, Vol. 8 No. 2, pp. 1-13.

Ramasamy, B. and Ting, H.W. (2004), "A comparative analysis of corporate social responsibility awareness: Malaysian and Singaporean firms", Journal of Corporate Citizenship, Vol. 13, pp. 109-123.

Richard, O.C., Barnett, T., Dwyer, S. and Chadwick, K. (2004), "Cultural diversity in management, firm performance, and the moderating role of entrepreneurial orientation dimensions", The Academy of Management Journal, Vol. 47 No. 2, pp. 255-266.

Rivas, J.L. (2012), "Diversity \& internationalization: The case of boards and TMTs", International Business Review, Vol. 21 No. 1, pp. 1-12.

Said, R., Zainuddin, Y. and Haron, H. (2009), "The relationship between corporate social responsibility disclosure and corporate governance characteristics in Malaysian public listed companies", Social Responsibility Journal, Vol. 5 No. 2, pp. 212-226.

Saleh, M., Zulkifli, N. and Muhamad, R. (2010), "Corporate social responsibility disclosure and its relation on institutional ownership: Evidence from public listed companies in Malaysia", Managerial Auditing Journal, Vol. 25 No. 6, pp. 591-613.

Sambasivan, M., Abdul, M. and Yusop, Y. (2009), "Impact of personal qualities and management skills of entrepreneurs on venture performance in Malaysia: Opportunity recognition skills as a mediating factor", Technovation, Vol. 29 No. 11, pp. 798-805.

Scholtens, B. (2008), "A note on the interaction between corporate social responsibility and financial performance", Ecological Economics, Vol. 68 No. 1-2, pp. 46-55.

Singh, V. and Vinnicombe, S. (2000), "Gendered meanings of commitment from high technology engineering managers in the United Kingdom and Sweden", Gender, Work and Organization, Vol. 7 No. 1, pp. 1-19.

Tabachnick, B.G. and Fidell, L.S. (2007), Using Multivariate Statistics, Fifth Edition, Pearson Education Inc., USA.

Talke, K., Salomo, S. and Rost, K. (2010), "How top management team diversity affects innovativeness and performance via the strategic choice to focus on innovation fields", Research Policy, Vol. 39 No. 7, pp. 907-918.

Tseng, Y. and Lee, T. (2009), "Comparing appropriate decision support of human resource practices on organizational performance with DEA/AHP model", Expert Systems with Applications, Vol. 36 No. 3, pp. 6548-6558.

Turner, J. C. (1985), "Social categorization and the self-concept: A social cognitive theory of group behavior", In E.J. Lawler (Ed.), Advances in Group Processes: Theory and Research, Vol. 2, pp. 77-122, JAI Press, Greenwich, CT.

Van der Laan Smith, J., Adhikari, A., Tondkar, R.H. and Andrews, R. L. (2010), "The impact of corporate social disclosure on investment behavior: A cross-national study", 
Journal of Accounting and Public Policy, Vol. 29 No. 2, pp. 177-192.

Van Ees, H., Van der Laan, G. and Postma, T.J.B.M. (2008), "Effective board behavior in the Netherlands", European Management Journal, Vol. 26 No.2, pp. 84-93.

Van Knippenberg, D., van Ginkel, W. P., and Homan, A. C. (2013), "Diversity mindsets and the performance of diverse teams", Organizational Behavior and Human Decision Processes, Vol. 121 No. 2, pp. 183-193.

Waddock, A.S. and Graves, B.S. (1997), "The corporate social performance financial performance link", Strategic Management Journal, Vol. 18 No. 4, pp. 303-319.

Wagner, T., Lutz, R.J. and Weitz, B.A. (2009), "Corporate hypocrisy: Overcoming the threat of inconsistent corporate social responsibility perceptions", Journal of Marketing, Vol. 73 No. 6, pp. 77-91.

Wallen, C. and Wasserfaller, M. (2008), "Internal organisationals factors influencing voluntary CSR disclosure-The case of three Swedish state-owned companies", Bachelor thesis, School of Business, Economics and Law, University of Gothenburg.

Wegge, J., Roth, C., Neubach, B., Schmidt, K., and Kanfer, R. (2008), "Age and gender diversity as determinants of performance and health in a public organization: The role of task complexity and group size", Journal of Applied Psychology, Vol. 93 No. 6, pp. 1301-1313.

Wu, W.L., Hsu, B.F. and Yeh, R.S. (2007), "Fostering the determinants of knowledge transfer: A team-level analysis", Journal of Information Science, Vol. 33 No. 3, pp. 326-339.

Yusoff, H., Mohamad, S.S. and Darus, F. (2013), "The influence of CSR disclosure structure on corporate financial performance: Evidence from stakeholders' perspectives", Procedia Economics and Finance, Vol. 7, pp. 213-220. 
APPENDIX A

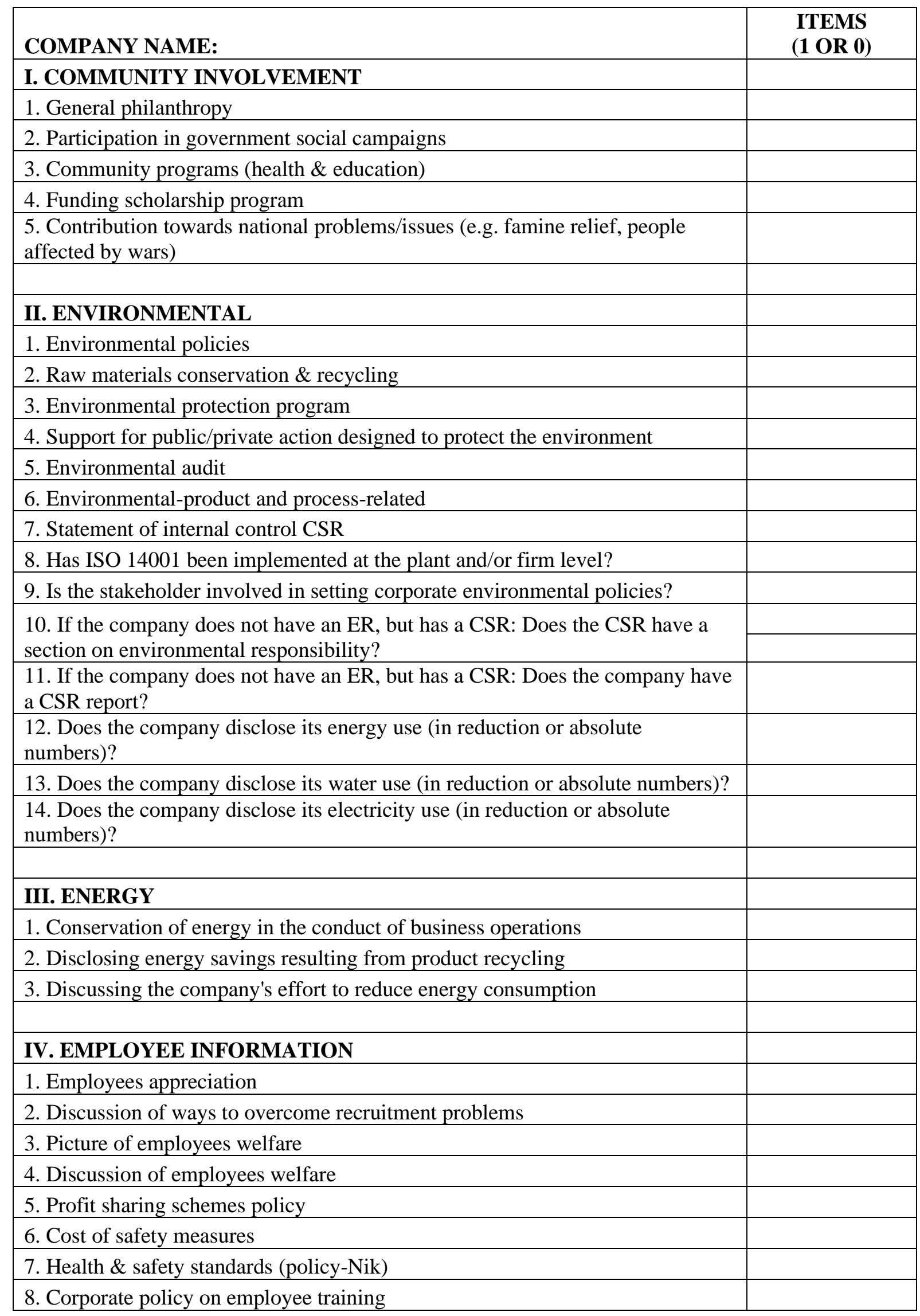




\begin{tabular}{|l|l|}
\hline 9. Nature of training & \\
\hline 10. Breakdown of employees by level of qualification/exec vs. non-execs CSR & \\
\hline $\begin{array}{l}\text { 11. Supporting nation pride (e.g. sponsorship for Formula 1, SUKMA, national } \\
\text { soccer team) }\end{array}$ & \\
\hline 12. No discrimination against race, gender, age and minorities & \\
\hline & \\
\hline V. PRODUCT OR SERVICE INFORMATION & \\
\hline 1. Discussion of major types of products & \\
\hline 2. Pictures of major types of products & \\
\hline 3. Improvement in product quality & \\
\hline 4. Improvement in customer services & \\
\hline 5. Distribution of marketing network for finished products-foreign market & \\
\hline 6. Customer awards/ratings received & \\
\hline 7. Product development & \\
\hline 8. Consumer information & \\
\hline & \\
\hline VI. VALUE-ADDED INFORMATION & \\
\hline 1. Value-added statement & \\
\hline 2. Qualitative value-added statement & \\
\hline 3. Value-added data/ratios & \\
\hline TOTAL & \\
\hline INDEX SCORE (over 45 items) & \\
\hline
\end{tabular}

${ }^{\text {i }}$ Sample size, $\mathrm{ss}=\frac{Z^{2} *(p) *(1-p)}{C^{2}}$ where, $Z=Z$-value (e.g., 1.96 for a 95 percent confidence level), $p=$ Percentage of population picking a choice, expressed as decimal (0.5) and $C=$ Confidence interval, expressed as decimal (e.g. $0.05= \pm 5$ )

${ }^{\text {ii }}$ Heterogeneity index $=1-\sum P_{i-n}^{2}$ where, $P=$ proportion of group members in the category, $\mathrm{i}$ $=$ each different category represented on a team, $\mathrm{n}=$ total number of categories 